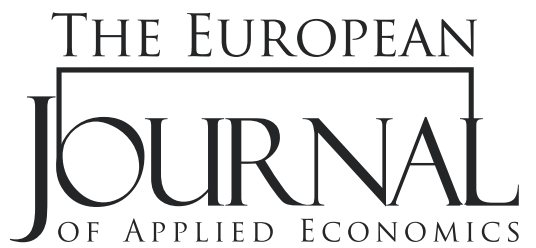

EJAE 2018, 15(2): 58-73

ISSN 2406-2588

UDK: 005.342:334.713(549.3)

330.34

DOI: 10.5937/EJAE15-17015

Original paper/Originalni naučni rad

\title{
CONSTRAINTS TO SMALL AND MEDIUM-SIZED ENTERPRISES DEVELOPMENT IN BANGLADESH: RESULTS FROM A CROSS-SECTIONAL STUDY
}

\author{
Md. Shahidul Islam ${ }^{1,2, *}$, Md. Faruk Hossain ${ }^{1}$ \\ ${ }^{1}$ Bangladesh Knitwear Manufacturers and Exporters Association (BKMEA), \\ Dhaka, Bangladesh. \\ ${ }^{2}$ Bangladesh Institute of Social Research (BISR) Trust, \\ Dhaka, Bangladesh.
}

\begin{abstract}
:
Small and Medium Enterprises (SMEs) are the significant contributor to the Bangladesh economy as they have the competency to create higher employment, improve local technology, and create ground for the future sustainable industrialization and corporate sectors. The aim of this study is to identify major constraints faced by the SMEs in Bangladesh.

A cross-sectional study was conducted in Narsingdi Municipality, Bangladesh and social survey method was applied to collect the data. Two-stage cluster sampling method was utilized to select respondents and data were collected through face-to-face interview. Principal Component Analysis (PCA) was used to determine significant constraints to SMEs. The study found that poor infrastructure and electricity supply are the main constraints to the development of SMEs. Limited access to credit, lack of proper business knowledge and plan, high domestic market competition, lack of skilled manpower and technology, and high cost of raw materials and equipment are the major constraints next to main constraint.
\end{abstract}

\section{Article info:}

Received: May 28, 2018

Correction: June 24, 2018

Accepted: June 27, 2018

\section{Keywords:}

small and medium-sized enterprises (SMEs), constraints, principal component analysis (PCA), Bangladesh.

\section{INTRODUCTION}

There is growing evidence that nurturing Small and Medium Enterprises (SMEs) has been playing a vital role in the economic development, especially in developing countries. SMEs have been considered as a powerful tool for boosting up the economic growth by creating new employment opportunities, improving local technologies, developing entrepreneurships, integrating with large-scale industries and international trade (ACMA, 2015). These have been considered as the main driver of businesses in developing countries, created ground for the future sustainable industrialization, developed 
entrepreneurial skills and fostered private ownerships (Moktan, 2007). Development of entrepreneurship and human skills can be considered as two driving forces of sustainable economic and social development (Tambunan, 2009) where establishing SMEs is the main strategy to develop entrepreneurship and human skills. Evidence supports that Japan has achieved its financial development based on SMEs (Chowdhury, 2003).

Despite having sufficient manpower Bangladesh cannot properly utilize it. Through SMEs, it is possible to create more employment opportunities with small capital comparing to large industries where its manpower can be utilized for productive outcome. SMEs can be developed in backward industry that will generate job opportunities for the semi-skilled and unskilled labour (Chowdhury, 2013).

SMEs have the ability to survive in poor economic condition because they are flexible in nature and can adopt with the changing market trend compared to larger industries (Zaman and Islam, 2011). Evidence supports that SMEs are more innovative than larger farms, facilitate the market with new innovation, and lead to technological changes (Acs et al. 1999). In addition, SMEs require relatively small capital, less infrastructural support and consumption of utilities, and less time to start up business and have quick returns (Chowdhury, 2013). Moreover, SMEs do not necessitate highly sophisticated expertise and technology. They can sustain using local resources and can be operated by trained manpower rather than sophisticated technology. SMEs are suitable for domestic market that can be run by utilizing local limited resources.

The productivity of SMEs largely depends on its ability to innovate, adopt new technologies and apply them to local conditions. The competitive advantage and ability of SMEs to trade in a global environment largely depend on the innovation (Berry et al. 2002). SMEs provide the nursery and pre-background of innovation (Wolf, 2006). Evidence supports that many scientific innovations were originated by small organizations like as photocopier, helicopter, insulin, zipper, stenographic pen, etc. (Longenecker et al. 1997).

SMEs can be run in local areas where the large enterprises cannot. The evidence also supports that most of the large enterprises, even the international multi-million dollar enterprises, have their origin in SMEs (National Credit Regulator, 2011). SMEs have great impact on rural economy because of their widely spreading presence across the rural areas and also have the capacity to employ large amount of labour force (Tambunan, 2011).

From the economic perspective, enterprises are considered for both suppliers and consumers. So, they can play an important role in the market if they have enough power to control those capabilities. SMEs are the main consumer for the raw materials produced domestically or internationally. Any increase in their demand for consumer goods will stimulate the activity of their suppliers, thus this activity is stimulated by the demand of their clients (Berry et al. 2002). If SMEs create demands in the market, they also play the role of supplier as well as consumer. So, generating effective demand is an important role of SMEs for establishing new SMEs and new income generation activity. SMEs contribute to the national economies by producing manufacturing goods of value or by fulfilling the demand of consumers or other enterprises (Abor and Quartey, 2010).

Although SMEs are the driving force of the economy, the mounting of a new SME development is not innate proceeding. Even the development of SMEs is not easy; it is often hampered by different external and internal constraints. These constraints may differ from area to area, rural to urban, among sectors and, among entrepreneurs within a sector (Tambunan, 2011). In Bangladesh, the establishment of SMEs is facing various problems related to raw materials, power, land, marketing, transport, technical facilities and finance. Poor capital structure and other constraints hamper the growth and function of SMEs 
(Quader and Abdulla, 2009). These constraints are very complex and interrelated also. There are a small number of studies in Bangladesh that have investigated constraints to SMEs development. This study is designed to determine the most relevant constraints hampering the SMEs development in Bangladesh.

\section{Definition of the SMEs}

Definition: There are so many definitions of SMEs that differ from country to country, depending on their size, scope and sector. Bangladesh Bank (2011) has defined the SMEs as follows:

\begin{tabular}{ccc}
\hline Sectors & $\begin{array}{c}\text { Fixed Asset other than } \\
\text { Land and Building }(\mathbf{B D T})^{*}\end{array}$ & $\begin{array}{c}\text { Employed Manpower } \\
\text { (not above) }\end{array}$ \\
\hline Service & 5.00 lakh -1.00 crore & $10-25$ \\
\hline Business & 5.00 lakh -1.00 crore & $10-25$ \\
\hline Industry & 50.00 lakh- 10.00 crore & $25-99$ \\
\hline
\end{tabular}

Table 1. Small Enterprise

Source: Bangladesh Bank (2011), *BDT=Bangladesh Taka, 1 lakh $=100$ thousands

In service unit, an enterprise is treated as small if in the current market prices, the replacement cost of its fixed asset (excluding land and buildings) is BDT 5 lakh to 1 crore, with employment size ranging from 10 to 25. In Business unit, an enterprise is treated as small if in the current market prices, the replacement cost of its fixed asset (excluding land and buildings) is BDT 5 lakh to 1 crore, with employment size up to number of employee ranges from 10 to 25. In Industrial unit, an enterprise is treated as small if in the current market prices, the replacement cost of its fixed asset (excluding land and buildings) is BDT 50 lakh to 10 crores with employment size ranging from 25 to 99.

\begin{tabular}{ccc}
\hline Sectors & $\begin{array}{c}\text { Fixed Asset other than } \\
\text { Land and Building }(\text { BDT })\end{array}$ & $\begin{array}{c}\text { Employed Manpower } \\
\text { (not above) }\end{array}$ \\
\hline Service & 1.00 crore- 15.00 crore & $50-100$ \\
\hline Business & 1.00 crore- 15.00 crore & $50-100$ \\
\hline Industry & 10.00 crore -30.00 crore & $100-250$ \\
\hline
\end{tabular}

Table 2. Medium Enterprise

Source: Bangladesh Bank (2011)

In service units, an enterprise is treated as medium if in the current market prices, the replacement cost of its fixed asset (excluding land and buildings) is BDT 1 crore to Tk. 15 crores with employment size up to number of employee ranges from 50 to 100. In Business unit, an enterprise is treated as medium if in the current market prices; the replacement cost of its fixed asset (excluding land and buildings) is BDT 1 core to Tk. 15 crore with employment size up to number of employee ranges from 50 to 100. In Industrial unit, an enterprise is treated as medium if in the current market prices; the replacement cost of its fixed asset (excluding land and buildings) is BDT 10 crore to Tk. 30 crore with employment size up to number of employee ranges from 100 to 250. 


\section{Contribution of SMEs to the economy}

\begin{tabular}{ccccccccccc}
\hline $\begin{array}{c}\text { Activity } \\
\text { /sector }\end{array}$ & $\begin{array}{c}\mathbf{2 0 0 7 -} \\
\mathbf{2 0 0 8}\end{array}$ & $\begin{array}{c}\mathbf{2 0 0 8 -} \\
\mathbf{2 0 0 9}\end{array}$ & $\begin{array}{c}\mathbf{2 0 0 9 -} \\
\mathbf{2 0 1 0}\end{array}$ & $\begin{array}{c}\mathbf{2 0 1 0 -} \\
\mathbf{2 0 1 1}\end{array}$ & $\begin{array}{c}\mathbf{2 0 1 1 -} \\
\mathbf{2 0 1 2}\end{array}$ & $\begin{array}{c}\mathbf{2 0 1 2}- \\
\mathbf{2 0 1 3}\end{array}$ & $\begin{array}{c}\mathbf{2 0 1 3 -} \\
\mathbf{2 0 1 4}\end{array}$ & $\begin{array}{c}\mathbf{2 0 1 4 -} \\
\mathbf{2 0 1 5}\end{array}$ & $\begin{array}{c}\mathbf{2 0 1 5}- \\
\mathbf{2 0 1 6}\end{array}$ & $\begin{array}{c}\mathbf{2 0 1 6 -} \\
\mathbf{2 0 1 7}\end{array}$ \\
\hline Industry & 17.77 & 17.90 & 17.94 & 17.42 & 18.96 & 19.54 & 19.47 & 20.16 & 21.01 & 21.73 \\
\hline $\begin{array}{c}\text { Large } \\
\text { scale } \\
\text { and } \\
\text { medium } \\
\text { scale }\end{array}$ & 12.63 & 12.71 & 12.68 & 13.20 & 13.73 & 14.28 & 15.95 & 16.58 & 17.37 & 18.02 \\
\hline $\begin{array}{c}\text { Small } \\
\text { scale }\end{array}$ & 5.14 & 5.18 & 5.26 & 5.22 & 5.23 & 5.27 & 3.51 & 3.58 & 3.64 & 3.71 \\
\hline
\end{tabular}

Table 3. Sectoral share in GDP at constant prices (1995-1996)

Sources: Statistical pocketbook Bangladesh, FY2016-17

Data presented in Table 3 reveal that share of industry in the GDP had been increased between FY2007-08 to FY2016-2017. Industrial contribution was 17.77\% in FY2007-08 which was increased by $21.73 \%$ by FY2016-2017. It is also noticeable that major contribution has come from larger and medium scale industry which was gradually increasing. But the GDP share has been decreasing in small enterprise.

\begin{tabular}{ccc}
\hline Year & Growth Rate of Small \& Cottage Industry & Medium to Large Industry \\
\hline $2001-02$ & $7.69 \%$ & $4.6 \%$ \\
\hline $2002-03$ & $7.21 \%$ & $6.6 \%$ \\
\hline $2003-04$ & $7.45 \%$ & $6.95 \%$ \\
\hline $2004-05$ & $7.93 \%$ & $8.30 \%$ \\
\hline $2005-06$ & $9.21 \%$ & $11.41 \%$ \\
\hline $2006-07$ & $9.69 \%$ & $10.80 \%$ \\
\hline $2007-08$ & $7.1 \%$ & $7.38 \%$ \\
\hline $2008-09$ & $7.30 \%$ & $6.54 \%$ \\
\hline $2009-10$ & $8.17 \%$ & $6.27 \%$ \\
\hline $2010-11$ & $5.67 \%$ & $11.11 \%$ \\
\hline $2011-12$ & $6.58 \%$ & $10.76 \%$ \\
\hline $2012-13$ & $8.81 \%$ & $10.65 \%$ \\
\hline $2013-14$ & $6.33 \%$ & $9.32 \%$ \\
\hline $2014-15$ & $8.54 \%$ & $10.70 \%$ \\
\hline $2015-16$ & $9.06 \%$ & $12.26 \%$ \\
\hline $2016-17$ & $9.21 \%$ & $11.32 \%$ \\
\hline
\end{tabular}

Table 4. Yearly Growth Rate of Small \& Cottage and Medium to Large Industry

Source: Bangladesh Economic Review, FY2016-17 
Data presented in Table 4 reveal yearly growth rate of small \& cottage and medium to large industry. In 2001-02, the growth rate of small enterprises was 7.69\%. In 2006-07, the growth rate of small enterprises had increased to $9.69 \%$. After this year the growth rate of small enterprises had decreased. In 2013-14, the growth rate of small enterprises was $6.33 \%$ and that was the lowest growth rate ever. In 2016-17, the growth rate of small industries was 9.21\%. Data presented in Table 4 clearly denote that the growth rate of the small enterprise has increased in recent years.

\section{REVIEW OF LITERATURE}

\section{Constraints to SMEs development}

There are various constraints identified to the development and operation of SMEs in Bangladesh. Quader and Abdulla (2009) identified financial constraints, regulatory constraints, and constraints on physical technical, and marketing input to SMEs' development in Bangladesh. They found that high lending rate, unavailability of financing, cost of high equipment, collateral need and small domestic market size, lack of technically skilled workers, lack of protective measures and uncertainty are major constraints to the development of SMEs in Bangladesh. They also added that high-interest rate is the major constraint to invest in SMEs of Bangladesh. Moktan (2007) examined major constraints of SMEs in Bhutan. He found that problems of business policies and regulatory, infrastructure and geophysical constraints, and finance are major constraints to SMEs development in this country. He also found that there were different constraints in urban and rural as per size, sector and ownership. Chowdhury (2007) investigated constraints to establish SMEs in Bangladesh. He found that inadequate infrastructure, lack of financial support, and political instability were major constraints. He suggested establishing political stability and rule of laws, enhancing infrastructure facilities and providing financial help to the entrepreneurs for developing SMEs in Bangladesh. Mambula (2002) investigated factors that influence the start-up, growth, and performance of SMEs in Nigeria. He found that lack of finance, poor infrastructure, access to raw materials were main constraints to SMEs' development in Nigeria. Moreover, lack of qualified and experienced entrepreneurs and untrained management were also constraints to SMEs' development. Kshetri (2011) examined various factors related to the entrepreneurship development and entrepreneurial performance in India. He found that regulatory framework, market conditions, access to finance, R\&D and technology related factors, physical infrastructures, entrepreneurial capabilities and entrepreneurial culture are affecting entrepreneurship performance and small business development.

\section{SMEs and Financing}

Chowdhury and Ahmed (2011) examined problems of SMEs' financing in Bangladesh. They explored that non-availability of sufficient credit, complex loan granting procedure, poor infrastructure facilities, troubles of collateral requirements, scarcity of working capital, lack of skilled workforce, poor salary structure, lack of coordination among SMEs related organizations, weak marketing strategies were constraints to SMEs' development in Bangladesh. They suggested that commercial banks and other financial institutions should make the SMEs' loan procedure easier. The Bangladesh Government may establish one specialized SME Bank to give collateral free bank loans to SMEs' entrepreneurs. Quartey (2015) examined the relationship between finance and SMEs in Ghana. He found that access to finance and location in a commercial town were the major determination of SMEs' growth. On the other hand, 
large initial capital, good exporting records and good profit of the firms were major determinations of access to finance for SMEs' development. Tambunan (2015) examined the recent development of SMEs in Indonesia with special consideration to identify constraints to SMEs' development. He found that lack of access to credit is the main constraint to SMEs' development in this country. Moreover, local entrepreneurs faced problems to explore their resources in market because there was low facility to capture market. They depend on their local network partners to reach the market. Hasan and Jamil (2014) identified that access to finance is the main constraint to SMEs' development in Bangladesh. Most of the banks in Bangladesh are less likely to give the loan to the SMEs' entrepreneur because they consider SME financing risky investment. Moreover, SMEs' entrepreneurs have insufficient knowledge on the procedure of seeking institutional finance. Abor and Biekpe (2006) found that access to finance is not only the main constraint to SMEs' development but also hampers the growth and performance of SMEs in Ghana. He found that access to credit is hampered by various factors like collateral requirement, poor knowledge of finance providers, stringent eligibility criteria, lack of knowledge about lending criteria and bureaucracy. Bhaird and Lucey (2010) examined determinations of the capital structure of SMEs in Ireland. He found that age, size, level of intangible activity, ownership structure and the provision of collateral are important determinants of the capital structure in SMEs. Aziz and Siddique (2006) explored that access to finance is the major driver for the development of SMEs in Bangladesh. They argued that pro-SME policy and friendly regulatory framework is essential for the sustainable SMEs' development. They found that Bangladesh Government and Bangladesh Bank have taken some policies that help to access the credit for SMEs' development.

\section{SMEs development and economic growth}

Peltier and Naidu (2012) investigated the effect of social networks on improving the organizational lifecycle performance in small to medium-sized enterprise (SME) in India. They found that advice from personal networks (family and friends) is helpful to start up a new SME as well as its functions. Hoque (2015) explored the role of information and communication technologies (ICTs) in SMEs' development in Bangladesh. They found that ICTs facilitate SMEs entrepreneurs to be more qualified in decisionmaking process. Using ICTs in SME has many benefits such as improving and reducing transaction costs, improving resource allocation, and shifting the production function. They found that the consciousness of benefits, support from government and financial support are important determinants of ICTs' use in SME in rural areas. Lack of electricity is one of the major obstacles to successful growth of SMEs in developing countries. Khandker (2014) identified that electricity supply is the prerequisite for SMEs' development as well as its success in both Bangladesh and Pakistan. Similarly, access to electricity and finance is not the only obstacle to SME's growth in South Asian countries, but it also has a negative impact on the growth of sales of the SMEs. He suggested that government should take necessary steps to provide financial support so that they start up new SMEs. Size of firms has also significant effect on the growth of SMEs. Middle sized firm grows faster than the small size farm. Abor and Quartey (2010) examined the contributions of SMEs to economic development and constraints to SMEs development in Ghana and South Africa. They found that $92 \%$ business is SMEs that contribute about $70 \%$ to Ghana's GDP. They recognized some factors constraints to SME's development such as lack of access to appropriate technology; limited access to international markets, the existence of inefficient laws, regulations and rules, poor institutional capacity, poor management skills and proper training, and finance. Beck et al. (2005) explored the relationship between SME's development and economic growth, poverty reduction in 45 countries across the world. They found that there is a strong positive 
association between SME's development and economic growth. But their results showed that there is no significant relationship between SME's development and poverty alleviation. Moreover, SME's development has no significant effect to reduce inequality.

\section{DATA AND METHOD}

Study area: Narsingdi Municipality was selected as the study area. It is $50 \mathrm{~km}$ north east from the capital of Bangladesh. It is a densely industrial area and famous for textile industry. This area is potential for various types of SMEs like fishery, fish feed, poultry feed, flat construction and plot trading, power loom, operation of construction firm and light engineering workshop (Bangladesh Bank, 2011).

Sampling: The cross-sectional research design was applied to the study because the survey was conducted at one point in time. Two-stage cluster sampling method was applied due to non-availability of sample. Narsingdi Municipality consists of nine wards. A ward is the lowest administrative tier of a city or town in Bangladesh that consists of several villages or mohallas (Islam, 2013). Three wards (wards no 2, wards no 7 and wards no 8) were randomly selected from nine wards (employment between 10 and 250). At the second stage, $132 \mathrm{SMEs}$ were selected randomly from these wards where the acceptable margin of error was .05 and t-value for the alpha level of .05 was 1.96.

Data collection: Social survey method was applied to the study and the data was collected through face-to-face interviews with respondents. Both closed-ended and open-ended questions were included in the questionnaire and data was collected through face-to-face interviews. The questionnaire had two parts: first part of the questionnaire contained the socio-economic information of respondents and at second section, questionnaire focused on the constraint to SMEs. There were 21 questions in this section, related to constrain to SMEs and respondents were given five options (strongly agree to strongly disagree) according to Likert scale.

\section{Data analysis}

The SPSS (Statistical Package for Social Science) 19 program was used to analyze the data. At first, factor analysis by extracting the Principal Components Analysis (PCA) using varimax normalized method was applied to identify the significant constraint to this study. Then, constraints were detected by ranking, according to factor loading, so that constraints could be identified according to their severity.

\section{Principle components analysis}

There are some rationales to use PCA: (1) it reduces and summarizes the 21 variables in fewer number factors that contains the major information of the original variable.(2) to find the amount of each common factor possessed by each observation(the factor scores). (3) it explores the relationship between observed variable(measurements) and the underlying latent factors. (4) It also calculates the variance of each variable and identifies the structure in correlation between the variables (Moktan, 2003).(5) Finally, to find and determine which of the variables contained in these factors are the most important of all constraints in the SME's development in Bangladesh.

The principal component variables y1, y2, .., yq are defined to be linear combinations of the original variables $\mathrm{x} 1, \mathrm{x} 2, \ldots, \mathrm{xq}$ that are uncorrelated and account for maximal proportions of the variation in the original data, i.e., yl accounts for the maximum amount of the variance among all possible linear 
combinations of $\mathrm{x} 1, \ldots, \mathrm{xq}, \mathrm{y} 2$ accounts for the maximum variance subject to being uncorrelated with $\mathrm{y} 1$ and so on. Explicitly, the principal component variables are obtained fromx1, .., xq as follows:

$$
\begin{aligned}
& Y_{1}=a_{11} X_{1}+a_{12} X_{2}+\ldots+a_{1 n} X_{n} \\
& Y_{2}=a_{21} X_{1}+a_{22} X_{2}+\ldots+a_{2 n} X_{n} \\
& ---------------- \\
& Y_{n}=a_{n 1} X_{1}+a_{n 2} X_{2}+\ldots+a_{n n} X_{n}
\end{aligned}
$$

\begin{tabular}{|c|c|}
\hline No & Variable \\
\hline 1 & Low profit due to domestic competition \\
\hline 2 & Limited access to market/small domestic market \\
\hline 3 & Lack of long standing customer relationship \\
\hline 4 & Duration too short/repayment schedule \\
\hline 5 & Hartal (strike) \\
\hline 6 & Limited access to credit/inadequate loan size \\
\hline 7 & Collateral requirement/Insufficient collateral possessed by most SMEs \\
\hline 8 & Interest rate high \\
\hline 9 & Lack of government support and assistance \\
\hline 10 & Lack of feasibility study and proper business plan \\
\hline 11 & Lack of information on technical and marketing aspects of SMEs \\
\hline 12 & Lack of management knowledge \\
\hline 13 & Legal and regulatory framework \\
\hline 14 & Scarcity of technical skill \\
\hline 15 & Inability of skilled manpower \\
\hline 16 & Lack of both public and private sector backed credit guarantee schemes for SME financing \\
\hline 17 & High cost of equipment \\
\hline 18 & High cost of raw materials \\
\hline 19 & Lack of entrepreneurship education and training \\
\hline 20 & Poor infrastructure \\
\hline 21 & Problem of power supply \\
\hline
\end{tabular}

Where, the coefficients aij $(i=1, \ldots, q, j=1, \ldots, q)$ are chosen fulfilling the conditions of maximal variance and no correlation ( Vyas and Kumaranayake, 2006).

\section{Variable of the study}

Table 5. Variable of the study 


\section{RESULT OF THE STUDY}

\begin{tabular}{|c|c|c|c|c|c|c|c|c|c|c|c|c|c|c|c|c|c|c|c|c|c|}
\hline & 1 & 2 & 3 & 4 & 5 & 6 & 7 & 8 & 9 & 10 & 11 & 12 & 13 & 14 & 15 & 16 & 17 & 18 & 19 & 20 & 21 \\
\hline 1 & 1. & & & & & & & & & & & & & . & & & & & & & \\
\hline 2 & .881 & 1 & & & & & & & & & & & & & & & & & & & \\
\hline 3 & .344 & .397 & 1 & & & & & & & & & & & & & & & & & & \\
\hline 4 & .069 & .132 & .073 & 1 & & & & & & & & & & & & & & & & & \\
\hline 5 & .965 & .880 & .326 & .105 & 1 & & & & & & & & & & & & & & & & \\
\hline 6 & .291 & .246 & .175 & -.104 & .322 & 1 & & & & & & & & & & & & & & & \\
\hline 7 & .281 & .201 & .138 & -.185 & .315 & .729 & 1 & & & & & & & & & & & & & & \\
\hline 8 & .196 & .146 & .206 & -.263 & .203 & .429 & .639 & 1 & & & & & & & & & & & & & \\
\hline 9 & .249 & .195 & .237 & -.181 & 223 & .226 & .444 & .506 & 1 & & & & & & & & & & & & \\
\hline 10 & .256 & .202 & .234 & -.192 & .253 & .231 & .444 & .502 & .995 & 1 & & & & & & & & & & & \\
\hline 11 & .194 & .204 & .482 & -.307 & .219 & .273 & .237 & .303 & .397 & .404 & 1 & & & & & & & & & & \\
\hline 12 & 199 & .225 & .482 & -.297 & .224 & .224 & .188 & .265 & .371 & .378 & .966 & 1 & & & & & & & & & \\
\hline 13 & .331 & .340 & .432 & -.018 & .362 & .354 & .506 & .402 & .372 & .381 & .428 & .417 & 1 & & & & & & & & \\
\hline 14 & .352 & .325 & .148 & .052 & .349 & .144 & .136 & .102 & .200 & .208 & .011 & .034 & .153 & 1 & & & & & & & \\
\hline 15 & -.008 & -.012 & .243 & -.052 & .016 & .183 & .202 & .547 & .282 & .257 & .108 & .110 & .163 & -.058 & 1 & & & & & & \\
\hline 16 & -.086 & -.018 & .027 & .064 & -.061 & .017. & -.102 & .123 & -.099 & -.114 & .004 & .028 & -.118 & -.062 & .364 & 1 & & & & & \\
\hline 17 & .026 & .015 & .297 & -.026 & .045 & .204 & .215 & .535 & .272 & .245 & .171 & .171 & .221 & -.021 & .924 & .419 & 1 & & & & \\
\hline 18 & .296 & .281 & .470 & -.262 & .326 & .443 & .375 & .262 & .289 & .298 & .843 & .832 & .612 & -.002 & .049 & -.044 & .116 & 1. & & & \\
\hline 19 & .225 & .152 & .057 & -.158 & .184 & .125 & .203 & .314 & .384 & .393 & .218 & .206 & .160 & .115 & .049 & -.030 & -.010 & .102 & 1. & & \\
\hline 20 & .258 & .194 & .119 & .044 & .191 & -.016 & -.155 & -.265 & -.123 & -.112 & .079 & .100 & -.030 & .149 & .364 & -.206 & -.320 & .095 & .257 & 1. & \\
\hline 21 & .040 & .107 & .014 & .951 & .075 & .142 & -.232 & -.318 & -.231 & -.240 & -.338 & -.327 & -.082 & .041 & .104 & .107 & -.078 & -.301 & -.196 & .017 & 1 \\
\hline
\end{tabular}

Table 6. Correlation of the variable

\begin{tabular}{lc}
\hline Kaiser-Meyer-Olkin(KMO) & 0.746 \\
\hline Bartlett's Test of Sphericity & \\
\hline Approx. Chi-Square & 5249.038 \\
\hline Degree of freedom & 210 \\
\hline Significant & 0.000 \\
\hline
\end{tabular}

Table 7. Measure of the sample adequacy

Bartlett's Test of Sphericity was applied to measure the sampling adequacy for PCA analysis. The KMO measures the sampling adequacy which should be greater than 0.5 for a satisfactory factor analysis to proceed. Looking at the table above, the KMO measure was 0.746 . High value generally indicates that a factor analysis may be useful with sample data. The same table shows that the Bartlett's test of sphericity was significant. The test's associated probability was less than 0.05 . In fact, it was actually 0.000 . This means that the correlation matrix was not an identity matrix.

\begin{tabular}{|c|c|c|c|c|c|c|c|c|c|}
\hline \multirow{2}{*}{$\begin{array}{l}\text { Com- } \\
\text { ponent }\end{array}$} & \multicolumn{3}{|c|}{ Initial Eigenvalues } & \multicolumn{3}{|c|}{$\begin{array}{l}\text { Extraction Sums of } \\
\text { Squared Loadings }\end{array}$} & \multicolumn{3}{|c|}{$\begin{array}{l}\text { Rotation Sums of } \\
\text { Squared Loadings }\end{array}$} \\
\hline & Total & $\begin{array}{c}\% \text { of } \\
\text { Variance }\end{array}$ & $\begin{array}{c}\text { Cumulative } \\
\%\end{array}$ & Total & $\begin{array}{c}\% \text { of } \\
\text { Variance }\end{array}$ & $\begin{array}{c}\text { Cumulative } \\
\%\end{array}$ & Total & $\begin{array}{c}\% \text { of } \\
\text { Variance }\end{array}$ & $\begin{array}{c}\text { Cumulative } \\
\%\end{array}$ \\
\hline 1 & 6.088 & 28.991 & 28.991 & 6.088 & 28.991 & 28.991 & 3.429 & 16.328 & 16.328 \\
\hline 2 & 3.109 & 14.804 & 43.794 & 3.109 & 14.804 & 43.794 & 3.172 & 15.106 & 31.434 \\
\hline 3 & 2.461 & 11.719 & 55.513 & 2.461 & 11.719 & 55.513 & 2.616 & 12.456 & 43.890 \\
\hline 4 & 1.887 & 8.987 & 64.500 & 1.887 & 8.987 & 64.500 & 2.494 & 11.876 & 55.766 \\
\hline 5 & 1.371 & 6.528 & 71.028 & 1.371 & 6.528 & 71.028 & 2.397 & 11.412 & 67.178 \\
\hline 6 & 1.288 & 6.134 & 77.162 & 1.288 & 6.134 & 77.162 & 2.097 & 9.984 & 77.162 \\
\hline 7 & .946 & 4.507 & 81.668 & & & & & & \\
\hline
\end{tabular}




\begin{tabular}{cccc}
\hline 8 & .809 & 3.852 & 85.520 \\
\hline 9 & .755 & 3.597 & 89.117 \\
\hline 10 & .567 & 2.700 & 91.817 \\
\hline 11 & .436 & 2.077 & 93.894 \\
\hline 12 & .425 & 2.026 & 95.920 \\
\hline 13 & .306 & 1.455 & 97.375 \\
\hline 14 & .165 & .788 & 98.163 \\
\hline 15 & .132 & .630 & 98.793 \\
\hline 16 & .084 & .400 & 99.193 \\
\hline 17 & .066 & .314 & 99.506 \\
\hline 18 & .043 & .204 & 99.710 \\
\hline 19 & .030 & .142 & 99.852 \\
\hline 20 & .027 & .129 & 99.980 \\
\hline 21 & .004 & .020 & 100.000 \\
\hline
\end{tabular}

Extraction Method: Principal Component Analysis.

Table 8. Total variance explained

A six-factor solution explained 77.162 of the total variance (Table 8). The first factor explained the $28.991 \%$ of total variance. The second factor explained $14.804 \%$ of the total variance. The third factor contained items that explained $11.719 \%$ of the total variance. The fourth factor explained 8.897 of the total variance. The fifth factor explained $6.528 \%$ of the total variance. The six factors explained $6.13 \% 3 \mathrm{of}$ the total variance. All the remaining factors are not significant.

\section{Scree Plot}

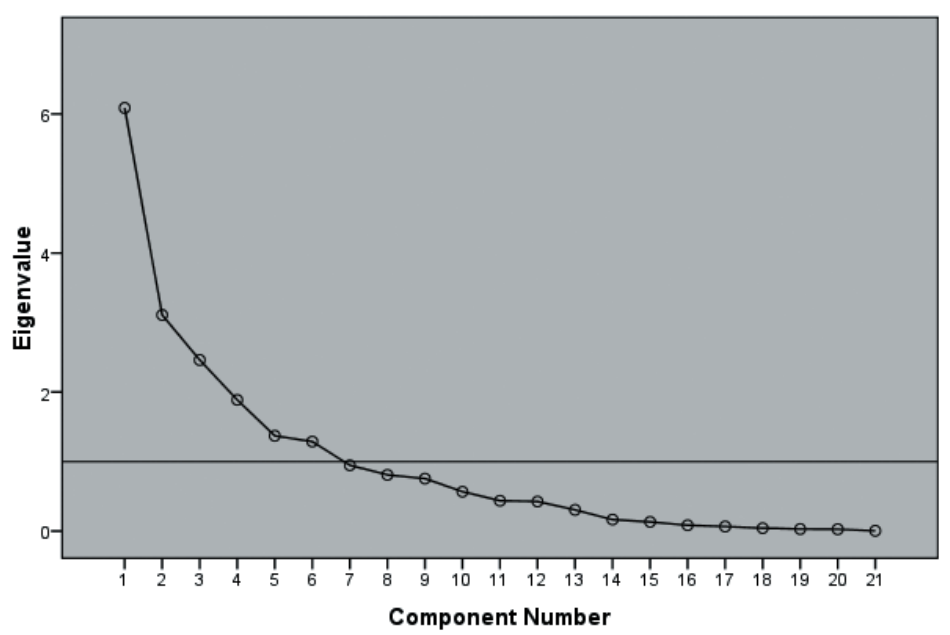

Figure 1. Scree plot showing the eigenvalues associated with each factor 
Figure 1 shows that there are 6 factors with an eigenvalue of more than 1. Moreover, Table 8 also shows that factor 7 has an eigenvalue of less than 1 . The figure showed that the curve begins to flatten between factors 6 and 7. So, only six factors (with an eigenvalue of $>1$ ) have been retained.

\begin{tabular}{|c|c|c|c|c|c|c|}
\hline & \multicolumn{6}{|c|}{ Component } \\
\hline & 1 & 2 & 3 & 4 & 5 & 6 \\
\hline Low profit due to domestic competition & .911 & .057 & .041 & .176 & .015 & .215 \\
\hline Limited access to market/small domestic market & .906 & .034 & .029 & .195 & .073 & 218 \\
\hline Lack of long standing customer relationship & .875 & .113 & .055 & .007 & .325 & .160 \\
\hline Duration too short/repayment schedule & .643 & .297 & .225 & .081 & .000 & .193 \\
\hline Hartal (strike) & .514 & .181 & .026 & .215 & .509 & .144 \\
\hline Limited access to credit/inadequate loan size & .149 & .932 & .020 & .095 & .153 & .016 \\
\hline $\begin{array}{l}\text { Collateral requirement/Insufficient collateral possessed by most } \\
\text { SMEs. }\end{array}$ & .171 & .910 & .004 & .071 & .206 & .060 \\
\hline Interest rate high & .201 & .893 & .016 & .031 & .100 & .098 \\
\hline Lack of government support and assistance & .091 & .487 & .068 & .260 & .041 & .049 \\
\hline Lack of feasibility study and proper business plan. & .139 & .010 & .904 & .131 & .141 & .010 \\
\hline Lack of information on technical and marketing aspects of SMEs & .062 & .046 & .901 & .150 & .151 & .014 \\
\hline Lack of management knowledge & .010 & .025 & .640 & .207 & .192 & .008 \\
\hline Legal and regulatory framework. & .151 & .371 & .452 & .040 & .307 & .078 \\
\hline Scarcity of technical skill & .226 & .088 & .104 & .891 & .212 & .045 \\
\hline Unavailability of skilled worker & .220 & .081 & .131 & .894 & .209 & .035 \\
\hline $\begin{array}{l}\text { Lack of both public and private sector backed credit guarantee } \\
\text { schemes for SME financing. }\end{array}$ & .045 & .236 & 105 & .579 & .065 & .243 \\
\hline High cost of equipment & .088 & .137 & .057 & .258 & .876 & .121 \\
\hline High cost of raw materials & .176 & .214 & .067 & .029 & .792 & .101 \\
\hline Lack of entrepreneurship related education and training & .101 & .094 & .480 & .417 & .518 & .234 \\
\hline Poor infrastructure & .120 & .109 & .001 & .098 & .079 & .944 \\
\hline problem of power supply & .156 & .090 & .019 & .145 & .116 & .929 \\
\hline
\end{tabular}

Extraction method: Principal Component Analysis.

Rotation method: Varimax with Kaiser Normalization.

Table 9. Rotated Component Matrix

Here, Factor 1 explains variables; low profit due to domestic competition, small domestic market, lack of long standing customer relationship and this factor interpreted as domestic market competition. 
Factor 2 explains variables having limited access to credit, insufficient collateral possessed by most SMEs, and high interest rate and therefore, theses three variables are grouped into one.

Factor 3 explains variables having lack of feasibility study and proper business plan and lack of information on technical and marketing aspects of SMEs - and therefore, it is grouped as a factor related to lack of proper business knowledge and plan of SMEs.

Factor 4 explains variables related to scarcity of technical skill and unavailability of skilled worker -and therefore, this is related to lack of skilled workers and technology.

Factor 5 explains two variables, high cost of equipment and high cost of raw materials - and so it may be inferred as a factor related to the high cost of raw material and equipment.

Factor 6 explains variables having poor infrastructure and problem of power supply -and it is related to poor infrastructure and electricity.

\begin{tabular}{lcc}
\hline \multicolumn{1}{c}{ Factor } & Factor loading Mean & Rank \\
\hline Domestic market competition & 0.897 & 4 \\
\hline Problem access to credit & 0.911 & 2 \\
\hline Lack of proper business knowledge and plan of SMEs & 0.903 & 3 \\
\hline Lack of skilled workers and technology & 0.893 & 5 \\
\hline High cost of raw material and equipment & 0.834 & 6 \\
\hline Poor infrastructure and electricity problem & 0.937 & 1 \\
\hline
\end{tabular}

Table 10. Summary of the factors

Finally, the results were ranked according to factor loading mean value (Table 10). Firstly, the result showed that poor infrastructure and electricity is the top constraint to the development of SMEs in Bangladesh. Secondly, problem access to credit affirmed the second highest constraint to SMEs' development. In addition, lack of proper business knowledge and plan of SMEs and domestic market problem competition hold the third and fourth constrain to SMEs. Lastly, lack of skilled workers and technology; high cost of raw material and equipment are the fifth and sixth problem to SMEs' development.

\section{DISCUSSION}

This study tried to identify major constraints to SMEs' development in Bangladesh. This study revealed that poor infrastructure and electricity are major constraints to SMEs' development in this country. The previous results showed that the lack of the electricity is the main constraint to SMEs' development in this South East Asia, especially in India, Pakistan and Bangladesh (Khandker, 2014). In addition, lack of consistency of the electricity supply is the most important problem that negatively affected not only SMEs' development but also hampered its productivity and sales.

For this reasons, SMEs' development in rural areas is more difficult than in urban area. In rural area, electricity supply is quite poor; some rural areas even have no electricity supply.

In urban area shortage of electricity supply hampers the productivity of the SMEs and sell of the product (Khandker, 2014). Vila and MacDonald (2013) showed in their study that about $13.2 \%$ of total annual sales have been lost due to electricity supply. 
Our study also found that poor infrastructure is also another vital constraint to SMEs' development in Bangladesh. The transportation infrastructure in Bangladesh is not properly developed and is especially poor in rural area. Product delivery is not possible in due time because of the poor infrastructure. For example, garments industry in Bangladesh need one month longer time compared to other competitive countries for purchasing order to delivery of the product (Chowdhury,2007). Poor transportation infrastructure and insufficient transport services result in high transportation cost that reduces the profit opportunity of the SMEs (Chowdhury, 2007).

Problems with access to credit, especially insufficient access to institutional and formal source of financing are considered as another major constraint to the growth of SMEs (Haque and Mahmud,2003). Financial institutions are less likely to give loans to SMEs due to high risk level associated with SMEs. Evidence supports that all the $60.4 \%$ SMEs certain financial problems, whereas $68.6 \%$ microenterprises faced problems in terms of accessing finance in Bangladesh (Vila and MacDonald, 2013). It is also observed that $74.9 \%$ SMEs faced financial problems while they were initializing new SMEs and repairing the older one (Vila and MacDonald, 2013).

High interest rate is also major constraint to SMEs' development. It also reduces the profit of the SMEs. All SMEs in Bangladesh have to pay average 15.6\% interest rate (Vila and MacDonald, 2013). It is also noted that banks are the major sources of formal loan of SMEs but the bank requires higher interest rate compared to other sources like as microfinance institutions, government related sources and private individuals. SMEs have to pay average $16.5 \%$ interest rate to the Bank whereas the rate is lower, $15.4 \%$, to other institutions (microfinance institutions and government related sources) and the interest rate is lowest to private individual -11.4\% (Vila and MacDonald, 2013).

Lack of proper business knowledge and plan of SME is another reason of failure to success in SMEs' development, especially microenterprises that have been established for a short time goal, and have no proper plan for the long run. The main purpose of the growth of some small enterprise is to fulfill the demand of the present market situation. They have no proper long time goal even have no idea on how to adopt if the market condition changes. As a result, most small enterprises have been closed because they could not adapt to the new market situation. Large industries have strong R\&D that is capable to measure present market condition and evaluate the future market condition, and can take the long time business plan.

Domestic market competition is also constraint to SMEs' development in Bangladesh. Manufacturing and SMEs of the RMG sector also have to take the challenges of global competition. But within the country, the formal SMEs have to be competitive with informal agents to supply the same market segment (Vila and MacDonald, 2013). Most micro-companies do not have a clear strategy to deal with more fierce competition beyond price competition (Vila and MacDonald, 2013). Small companies have lack of syndicate to negotiate with larger companies (Vila and MacDonald, 2013).

Larger industries have the policy to adopt new technologies in commercial intelligence. But SMEs do not have those types of efficiency and are not able to proficiency in technology development.

Large industries published their activities in public media through website or monthly, yearly in the form of books. One can easily trace their growth, profit, manpower, property from these sources. When they go to bank for demanding loan, the bank can easily observe the database and can recognize the large industry as a reputed organization. They generally choose the large industry for the loan. But SMEs have no record about their activities and may not publish their activities and as a result they are not identifiable in market easily. When they go to bank or other finance institution, the bank may not take the risk to give the smart loan to the unknown organization. 
Large industry has a research and development unit and a strong human resource management unit. They maintain updated information about the loan policy of government institutions and financial institutions, and even keep the proper information about entire bank's loan policy. They have proper knowledge about the process of loan and demand for loan - which banks' loan scheme is suitable for them. Moreover, large industry has been taking loan for the long time from the bank. They have good relation with the bank and the bank recognizes them as a trustworthy organization. Large industry can easily get the loan compared to small and medium industry. So, the poor management and accounts practices of the SMEs are also the reason to limited access to finances.

Banks require collateral for various types of loan. The small firms generally have not enough collateral or have no goodwill for taking the loan from any financial institutions. So, access to finance is one of the vital constraints to develop SMEs in Bangladesh. Without enough capital, it is very hard to start a business in Bangladesh. Lack of skilled workers and technology is also one of the constraints to SMEs' development. Most of the workers in SMEs are not properly skilled, and most of the small SMEs have no sophisticated technology.

\section{CONCLUSION}

This paper identified constraints to development of SMEs in Bangladesh. This study revealed that poor infrastructure and electricity are the main constraints to start up new SME. Access to finance is the second major problem to SME's development. Lack of proper business knowledge and plan of SMEs is also a major problem in Bangladesh. Most of the SMEs have been established without proper business knowledge even they have no long term business plan. Domestic market competition, lack of skilled manpower and high cost of raw materials also remain the constraints of SMEs' development in Bangladesh.

\section{REFERENCES}

Abor, J., \& Biekpe, N. (2006). Small business financing initiatives in Ghana. Problems and Perspectives in Management, 4(3), 69-77.

Abor, J., \& Quartey, P. (2010). Issues in SME development in Ghana and South Africa. International Research Journal of Finance and Economics, 39(6), 215-228.

Acma, M.Q. (2015). Productivity and Performance Evaluation of SME Sector in Bangladesh: Evidence from the Historical Data. Journal of Islamic Finance and Business Research, 3(1), 14-22.

Acs, Z.J., Morck, R., \& Yeung, B. (1999). Productivity growth and firm size distribution. In Z.J. Ács, B. Carlsson \& C. Karlsson (Ed.), Entrepreneurship, Small and Medium-Sized Enterprises and the Macroeconomy (pp. 367-396). Cambridge: Cambridge University Press.

Ahmed, K., \& Chowdhury, T.A. (2009). Performance evaluation of SMEs of Bangladesh. International Journal of Business and Management, 4(7), 126. DOI:10.5539/ijbm.v4n7p126

Aziz, T., \& Siddique, M.N.E.A. (2016). The Role of Bangladesh Bank in Promoting SMEs' Access to Finance in Bangladesh. International Journal of SME Development, 3(2), 103-118.

Bangladesh Bank. (2011). Small and Medium Enterprise (SME) Credit Policies \& Programmes. SME \& Special Programmes Department. Retrieved September 20, 2017, from https://www.bb.org.bd/sme/smepolicye.pdf

Bangladesh Bank. (2017). Industrial Credit Report. Retrieved September 20, 2017, from https://www.bb.org.bd/ openpdf.php 
Bangladesh Bureau of Statistics. (2017). 2017 Statistical Year Book Bangladesh. Retrieved September 20, 2017, from http://bbs.portal.gov.bd/sites/default/files/files/bbs.portal.gov.bd/page/b2db8758_8497_412c_a9ec_ 6bb299f8b3ab/S_Y_B2017.pdf

Beck, T., \& Demirguc-Kunt, A. (2006). Small and medium-size enterprises: Access to finance as a growth constraint. Journal of Banking \& Finance, 30(11), 2931-2943. DOI:10.1016/j.jbankfin.2006.05.009

Beck, T., Demirgüç-Kunt, A. S. L. I., \& Maksimovic, V. (2005). Financial and legal constraints to growth: does firm size matter? The Journal of Finance, 60(1), 137-177.

Beck, T., Demirguc-Kunt, A., \& Levine, R. (2005). SMEs, growth, and poverty: Cross-country evidence. Journal of Economic Growth, 10(3), 199-229. DOI:10.1007/s10887-005-3533-5

Beck, T., Demirgüç-Kunt, A., \& Maksimovic, V. (2008). Financing patterns around the world: Are small firms different? Journal of Financial Economics, 89(3), 467-487. DOI: 10.1016/j.jfineco.2007.10.005

Centre for Policy Dialogue. (2017). Bangladesh Economy in FY2016-17: Interim Review of Macroeconomic Performance. Retrieved September 20, 2017, from https://cpd.org.bd/wp-content/uploads/2017/06/BangladeshEconomy-in-FY2016-17-Interim-Review-of-Macroeconomic-Performance.pdf

Chowdhury, M. S. (2007). Overcoming entrepreneurship development constraints: the case of Bangladesh. Journal of Enterprising Communities: People and Places in the Global Economy, 1(3), 240-251. DOI: $10.1108 / 17506200710779549$

Chowdhury, M. S. A., Azam, M. K. G., \& Islam, S. (2015). Problems and prospects of SME financing in Bangladesh. Asian Business Review, 2(2), 51-58.

Chowdhury, T. A., \& Ahmed, K. (2011). An Appraisal of the Problems and Prospects of Small and Medium Enterprises (SMEs) Financing in Bangladesh: A Study on Selected Districts. Retrieved September 20, 2017, from http://dspace.ewubd.edu/handle/123456789/415

Dinhucha Gonçalves Fumo, N., \& Jose Chiappetta Jabbour, C. (2011). Barriers faced by MSEs: evidence from Mozambique. Industrial Management \& Data Systems, 111(6), 849-868. DOI: 10.1108/02635571111144946

Haque, A. K. E., \& Mahmud, S. (2003). Economic policy paper on access to finance for SMEs: Problems and Remedies. Retrieved September 20, 2017, from http://www.dhakachamber.com/economic_policy/Access_to_finance.pdf

Hasan, F., \& Jamil, G. M. H. (2014). Financing Small and Medium Enterprises in Bangladesh-Issues and Challenges. The Asian Journal of Technology Management, 7(1), 45-54.

Hoque, M. R., Saif, A. N. M., AlBar, A. M., \& Bao, Y. (2016). Adoption of information and communication technology for development: A case study of small and medium enterprises in Bangladesh. Information Development, 32(4), 986-1000.

Hossain, N. (1998). Constraints to SME Development in Bangladesh. College Park, MD: Institutional Reform and the Informal Sector, University of Maryland.

Khandke, A. (2014). Constraints and Challenges of SME Development in the Developing Countries: A Case Study of India, Pakistan and Bangladesh. International Journal of SME Development, 1(1), 87-118.

Kshetri, N. (2011). The Indian environment for entrepreneurship and small business development. Cluj-Napoca: Babes-Bolyai University.

Longenecker, J. G., Moore, C. W., Petty, W., \& Palich, L. E. (2005). Small business management: An entrepreneurial emphasis. Mason, OH: SWC Publishing.

Mac an Bhaird, C., \& Lucey, B. (2010). Determinants of capital structure in Irish SMEs. Small Business Economics, 35(3), 357-375. DOI:10.1007/s11187-008-9162-6

Mambula, C. (2002). Perceptions of SME growth constraints in Nigeria. Journal of Small Business Management, 40(1), 58. DOI:10.1111/1540-627X.00039

Moktan, S. (2007). Development of small and medium enterprises in Bhutan: Analysing constraints to growth. South Asian Survey, 14(2), 251-282. DOI:10.1177/097152310701400205 
Peltier, J. W., \& Naidu, G. M. (2012). Social networks across the SME organizational lifecycle. Journal of Small Business and Enterprise Development, 19(1), 56-73. DOI:10.1108/14626001211196406

Quader, S. M., \& Abdullah, M. N. (2009). Constraints to SMEs: A Rotated Factor Analysis Approach. South Asian Studies, 24(2), 334-350.

Quartey, P. (2003). Financing small and medium enterprises (SMEs) in Ghana. Journal of African Business, 4(1), 37-55.

Syed Manzur, Q. (2008). Constraints to SMEs: A Rotated Factor Analysis Approach. A Research Journal of South Asian Studies, 24(2), 334-350.

Tahi Hamonangan Tambunan, T. (2011). Development of small and medium enterprises in a developing country: The Indonesian case. Journal of Enterprising Communities: People and Places in the Global Economy, 5(1), 68-82. DOI:10.1108/17506201111119626

Vila, J., MacDonald, M. (2013). The state of the SME sector-the manufacturing SME sector in Bangladesh (2013): An overview. Draft working paper 3.

Vyas, S., \& Kumaranayake, L. (2006). Constructing socio-economic status indices: how to use principal components analysis. Health Policy and Planning, 21(6), 459-468.

Zaman, A.H., \& Islam, M.J. (2011). Small and medium enterprises development in Bangladesh: Problems and prospects. ASA University Review, 5(1), 145-160.

\section{OGRANIČENJA ZA RAZVOJ MALIH I SREDNJIH PREDUZEĆA U BANGLADEŠU: REZULTATI IZ UNAKRSNE STUDIJE}

\section{Rezime:}

Mala i srednja preduzeća (MSP) značajno doprinose ekonomiji Bangladeša jer imaju potencijal da kreiraju veću zaposlenost, poboljšaju lokalne tehnologije i stvore osnove za buduće održive industrijske i korporativne sektore. Cilj ove studije je da identifikuje glavna ograničenja sa kojima se suočavaju mala i srednja preduzeća u Bangladešu.

Unakrsna studija sprovedena je u opštini Narsingdi, dok je za prikupljanje podataka primenjena metoda anketiranja javnog mnjenja u Bangladešu. Metod uzorkovanja nasumično selektovanih kandidata u dve faze korišćen je za odabir ispitanika, a podaci su prikupljeni putem intervjua licem u lice. Analiza glavne komponente korišćena je za utvrđivanje značajnih ograničenja za MSP.

Studija je pokazala da su slaba infrastruktura i snabdevanje električnom energijom glavna ograničenja za razvoj malih i srednjih preduzeća. Ograničen pristup kreditima, nepostojanje odgovarajućeg poslovnog znanja i plana, velika konkurencija na domaćem tržištu, nedostatak kvalifikovanih radnika i tehnologija i visoki troškovi sirovina i opreme su glavna ograničenja.
Ključne reči:

mala i srednja preduzeća (MSP), ograničenja, analiza glavnih komponenti, Bangladeš. 